\title{
The IPOO-model of creative learning and the students' information processing characteristics
}

\author{
Katalin Mezö* and Ferenc Mező \\ University of Debrecen, Hajdúböszörmény, Hungary
}

\begin{abstract}
The present study was designed to examine secondary school students' information processing characteristics during learning and their relationship with the students' academic averages, internal motivation for learning and cognitive abilities, such as intelligence and creativity. Although many studies have previously focused on this issue, we are now studying this topic from the perspective of the IPOO-model, which is a new theoretical approach to school learning (note: IPOO is an acronym of Input, Process, Output, Organizing). This study featured 815 participants (secondary school students) who completed the following tests and questionnaires: Raven's Advanced Progressive Matrices (APM) intelligence test, the 'Unusual Uses' creativity test (UUT), the $2^{\text {nd }}$ version of the Jupiterbolha-próba (Jupiter Flea test - JB2) to test the information processing method of learning, and the Learning Attitude Questionnaire (LAQ). In our analysis we took the gender, school grade and academic average of participants into account. According to our results, the quality of information-processing methods of learning is at a low level, and there are no significant strong correlational relationships among the tests and questionnaire results (except in the cases of fluency, originality, and flexibility). There were no significant differences between genders or classes. These findings are consistent with the findings of previous studies.
\end{abstract}

Keywords: information processing, creativity, learning, IPOO-model, secondary school students

\section{IPOO-model ustvarjalnega učenja in značilnosti procesiranja informacij pri učencih}

\author{
Katalin Mező in Ferenc Mező \\ University of Debrecen, Hajdúböszörmény, Madžarska
}

Povzetek: Namen raziskave je bil preveriti, kako učenci v srednji šoli procesirajo informacije med učenjem in kakšen je odnos med značilnostmi procesiranja in njihovo učno uspešnostjo, notranjo motivacijo in kognitivnimi sposobnostmi, kot sta inteligentnost in ustvarjalnost. Čeprav so bile na tem področju v preteklosti že opravljene raziskave, se pričujoča študija te problematike loteva z vidika IPOO-modela, ki predstavlja nov teoretski pristop k šolskemu učenju (IPOO je akronim za Input (vnos), Process (proces), Output (izdelek), Organizing (organizacija)). V raziskavi je sodelovalo 815 dijakov, ki so izpolnili naslednje teste oziroma vprašalnike: Ravenove zahtevne matrice (APM), Test ustvarjalnosti »Nenavadne uporabe« (UUT), Jupiterbolha-próba test - druga verzija (JB2) za testiranje učne metode procesiranja informacij in Vprašalnik učnih stališč (LAQ). V raziskavo smo kot spremenljivke vključili tudi spol, razred in povprečno učno uspešnost sodelujočih učencev. Rezultati so pokazali nizek nivo kakovosti učne metode procesiranja informacij in nepovezanost med testnimi rezultati ter rezultati na vprašalnikih (razen v primeru fluentnosti, originalnosti in fleksibilnosti). Razlike med spoloma in razredi se niso izkazale kot statistično značilne. Ugotovitve so skladne z ugotovitvami predhodnih študij.

Ključne besede: procesiranje informacij, ustvarjalnost, učenje, IPOO model, dijaki

\footnotetext{
"Naslov/Address: Katalin Mezö, Department of Psychology and Special Education, Faculty of Child and Adult Education, University of Debrecen, Hajdúböszörmény, Hungary, e-mail: kata.mezo1@gmail.com
}

Članek je licenciran pod pogoji Creative Commons Attribution 4.0 International licence. (CC-BY licenca). The article is licensed under a Creative Commons Attribution 4.0 International License (CC-BY license). 
In the studies and theories which focus on the information processing related to creativity (for example early works of Cropley, 1997; Davis, 1992; Helmholtz, 1986; Kris, 1953; Stein, 1974; Wallas, 1926; Whiting, 1958; and others), we can find descriptions of a kind of neutral, general creative thinking which exists without specifically defined creative areas (e.g. cooking, painting, writing etc.). These theories and descriptions are generally sufficient, and are applicable in numerous situations; however, we must recognise that more specific models of creative process may be needed in different areas of culture and/or talent. One such area is school learning. However, creative learning is distinct from general creativity (which can be characterized by fluency, originality and flexibility), because of its focus on the creative information processing procedure involved in learning itself (Craft, Cremin, Burnard, \& Chappell, 2007; Jeffrey, 2006).

On the other hand, there are different models of school learning (for example Bloom, 1968; Bruner, 1961; Carroll, 1963; Galperin, 1989), but these models do not concentrate sufficiently on creative learning. In addition, neutral, general creativity is a frequent, but not central variable in studies of school learning (Cropley, 2003). In these studies general creativity is only one variable of the other background factors (for example intelligence, motivation, gender, age or school grades) of learning.

In this article we study learning from the perspective of the IPOO-model, which is a new theoretical approach to creative school learning (Mező, 2011).

\section{The IPOO-model of Learning}

According to the IPOO-model (built on a cognitive psychology basis), school learning is an information processing procedure, and has four components: input, process, output and organizing (Mező, 2011). Every component is built on the basis of special abilities, motivations, and methods.

Learning problems can be found in every component of the IPOO-model. For example some typical learning problems of the input phase are "What will the topic of learning be?", or "Where can I find information about my learning topic?", or "How can I use the authorities (authoritative sources) effectively?". Learning problems can occur in the process phase of learning - e.g. "I don't understand the text, or the lesson!" or "I have to learn too much. I cannot memorize everything..." Subsequently, learning problems can be encountered in the output phase, for example, "I hate oral exams.", "How can I write my dissertation?", or "How can I apply my knowledge in my life?" Last, but not least, organising-problems can include the classical problems of the time, the place and the cost of learning etc.

In this learning model, we can differentiate three information-processing possibilities based on the relationship between input and output: the informationprocessing method of learning may be reproductive, productive, or cause information loss (Table 1).
The main indication of deficient learning is that quantitative and qualitative characteristics feature less in the output (e.g. in an oral exam) than in the input (e.g. in a book), i.e. input $>$ output. If the input is greater than the output, the learning will be ineffective. For example, a poem has four stanzas (as input), but the learner can reproduce (as output) less than four verses. The most important characteristic of learning of this kind is information deficit.

In the case of reproductive learning, the input is same as the output (input = output). If the input is equal to the output, the learning will be reproductive without any creative information processing. For example, a poem has four stanzas (as input), and the learner can recite (as output) all of the four stanzas, but she/he does not understand the words, the stanzas, the poem, or the metaphors within the poem, etc. The learner tries to memorise the lesson word by word without the need for understanding, or basic processing.

Finally, productive learning can be described by the following inequality: input $<$ output. If the input is less than the output, learning will be meaningful, holistic and creative. For example, a poem has four stanzas (as input), and the learner (at the moments of output) can recite all of the four stanzas and she/he understands the poem, and she/he searches for the nexus between the new lesson and his/her earlier knowledge.

In the case of the IPOO-model, the learning ideal is creative, productive learning. If students' learning styles cause information loss or are reproductive, then learning development is needed (e.g. our applied learning developmental program is the "IPOO-minimum program").

\section{Background Factors of Learning}

The intrapersonal factors of learning have been studied for several decades. The most frequently identified factors of these studies include intelligence, creativity, and motivation. Researchers often use these factors to predict the learning achievement which is generally operationalized as an academic average. We provide a brief overview of these factors in the following section.

The role of intelligence in learning achievement has been a central question since the dawn of intelligence testing (consider, for example, the creation of Binet's intelligence test). According to a number of studies (e.g. Neisser et al., 1996; Sternberg \& Grigorenko, 2007), there is a relationship between IQ scores and school achievement (the value of the correlation is about $r=.50$ ). Researchers have long disagreed about the existence of gender differences in overall intelligence (Petersen \& Hyde, 2010). While we can find studies which have reported gender differences (e.g. Furnham, Clark , \& Bailey, 1999; Hyde, 2005; Lynn, Irwing \& Cammock, 2002), other studies find no gender differences in intelligence (e.g. Brody, 1992; Halpern \& LaMay, 2000; Jensen, 1998).

Researchers have been studying the relationship between creativity and learning since the fifties of 
Table 1. Examples of different processing approaches to an input (e.g. a school subject) text, and their possible outputs (the interpretative frame is the IPOO-model of learning)

INPUT:
$\begin{gathered}\text { Let us imagine that the } \\ \text { text of a school subject... }\end{gathered}$$\quad \rightarrow \quad \begin{gathered}\text { PROCESS } \\ \text { by: }\end{gathered} \quad \rightarrow \quad \begin{gathered}\text { OUTPUT: } \\ \text { In the case of an oral/written exam, we can } \\ \text { observe that the learner communicates... }\end{gathered}$

Productive (creative): re-editing

...a creative product: a non-confused text

...is a confused text (from the perspective of a learner or anybody else)
Reproductive: mechanical memorising of the input without re-editing (but re-editing is pos- ...a confused text (identical to the input text) sible in the future)

Information loss: not enough memorisation of the input text, making it impossible to re-edit ...nothing, or a more confused text than the it in the future (without re-learning, of course) original input text

Productive (creative): highlighting essen-

tial information and rejecting non-essential ...a creative product: highlighting the essence information

Reproductive: mechanical memorisation of

...is a mix of essential and non-essential explicit information

the input (without highlighting essentials - but .... text identical to the input

highlighting is possible in the future)

Information loss: not enough memorisation of essential and non-essential information of the input text so it is impossible to recall this in the future

.... a text with less explicit information than the input

Productive (creative): creating explicit con- ...creative products: explicit conclusions

clusions based on the text

Reproductive: mechanical memorisation of the input (without creating explicit conclusions - but this is possible in the future) .... a text identical to the input (without explicit conclusions)

Information loss: not enough memorisation of the input text, making it impossible to find ...a text that contains less implicit information explicit conclusions in the future than the input

...contains implicit information

Productive (creative): finding relationships among different paragraphs, texts and prior $\quad$...a creative product: holistic knowledge learning

Reproductive: mechanical memorising of the

...contains atomistic information in different paragraphs and/or chapters input (without looking for relations among pieces of information - but this is possible in

.... text that is a set of atomistic pieces of the future)

Information loss: not enough memorisation of the atomistic information of the input text so it is impossible to find relationships among non-memorised pieces of information in the .... text that is an incomplete set of atomistic future pieces of information from the input text 
several decades, the results are sometimes contradictory in the area of learning motivation, too. One of the few areas of consensus on this topic is that, in an ideal case, students have internal motivations for learning (Ryan \& Deci, 2000; Sullo, 2007).

As we have seen, research of the intrapersonal background factors of learning has a tradition stretching back several decades. A number of researchers have focused on the predictive roles and correlations of cognitive abilities (e.g. intelligence and creativity) and noncognitive factors (e.g. motivation) from the perspective of school achievement (e.g. academic average). Although these are classical and traditional variables of learning research, from time to time it is necessary to study these variables from the perspective of new learning theories (for example the IPOO-model of learning). Therefore, the aim of our study was to gain insight into secondary school students' characteristics in terms of information processing during (creative, productive) learning, and to analyse the relationships between these characteristics and cognitive abilities, internal motivation, and academic average. According to our classroom observations, these factors are fairly independent from each other, so we cannot use them as predictors of each other. We also addressed the issue of gender equality.

\section{Method}

\section{Participants}

Participants were $9^{\text {th }}$ to $12^{\text {th }}$ grade students with a mean age of 16.01 years $(S D=.97)$, attending two middle secondary schools in Hungary. The total number of participants was 815 . The sample was gender heterogeneous; about $25 \%$ of students $(n=202)$ were male. Two hundred and thirty-eight students were $9^{\text {th }}$ graders $\left(M_{\mathrm{age}}=14.96 ; S D=.42\right), 261$ were $10^{\text {th }}$ graders $\left(M_{\mathrm{age}}=\right.$ $16.08 ; S D=.65), 218$ students were $11^{\text {th }}$ graders $\left(M_{\text {age }}^{\text {age }}=\right.$ $16.91 ; S D=.38)$, and 98 students were $12^{\text {th }}$ graders $\left(M_{\text {age }}^{\text {age }}=\right.$ $17.60 ; S D=.52)$. Although this is an ad hoc sample, which is not representative enough, we think that this study can provide sufficient preliminary results for further examinations.

\section{Instruments}

Creative learning was measured with the Hungarian version of the JB2 test (the Jupiterbolha-próba or, in English, the "Jupiter Flea" test; Mezö, 2011). Its subscales refer to re-editing ("Do students create a new and systematically logical structure when they encounter a confused text?"), direct info-management ("Do students find the direct essential information in a text?"), indirect info-management ("Do students create conclusions?"), and holistic learning ("Do students look for relationships with their knowledge?"). The total score is the average of these subscales. For the purpose of this study, we used mainly the "total score" variable of this test to measure creative learning. The reliability of the total score of the JB2 was $\alpha=.78-.87$ (Mezö, 2011).

We used Raven's Advanced Progressive Matrices test (APM; Raven, Raven \& Court, 1998) for measuring general intelligence - for more information about the Hungarian adaptation of Raven's APM, see Rózsa (2006) and Mező and Kurucz (2014). Some researchers believe that scores on the Raven's Progressive Matrices test give the best estimate of general intelligence (the " $g$ factor"; see Jensen, 1998; McLaurin, Jenkins, Farrar \& Rumore, 1973). The APM has two different parts: APM-I (with 12 items) and APM-II (containing an extra 36 items for those who are good at APM-I). The total APM score is the sum of these parts. APM reliability is $\alpha=.85$.

Fluency, originality and flexibility (as classical creativity variables) were tested by applying the Unusual Uses Test (a subtest of the Torrance Tests of Creative Thinking, TTCT; Torrance, 1966), based on Guilford's Alternative Uses Task (Guilford, 1962). In this task subjects are asked to list as many uses as possible for a common household item (such as a brick, a pencil or a key). This task is the "Unusual Uses" subtest of the TTCT and it is used to measure such components of creative thinking as fluency (the sum of relevant answers), originality (the infrequency of responses), flexibility (differences in the categories of the responses), average originality (originality/fluency), and relative flexibility (flexibility/fluency). Barkóczi and Zétényi (1981) provide information about the adaptation of the "Unusual Uses" test for the Hungarian population. The $\alpha$ value of these tests ranges between .70 and .90 (Cropley, 2003).

Internal learning motivation was assessed by applying the Learning Attitude Questionnaire (LAQ; Kontra, 2006) which consists of 31 items with a five-point response scale ( $1=$ it is non typical of me; $5=$ it is typical of me). There are six subscales: further education ambitions, interest, predisposition to industrious learning, learning for a good rating, learning for a good position among peers, and learning for rewards. We used an "internal learning motivation" variable based on the mean of the first three subscales (the Cronbach $\alpha$ is .81; Kontra, 2006).

Our control variables were gender (male/female) and grades (grade $9^{\text {th }}, 10^{\text {th }}, 11^{\text {th }}$, and $12^{\text {th }}$ ).

\section{Procedure}

Participation was not obligatory in this study. The students and their parents were informed about the subject of the study before testing and they were able to make a decision about whether to participate or not. Consequently, our subjects had some kind of internal motivation to participate in this examination, so we did not need to use external motivators (e.g. money, good marks etc.) in order to involve participants.

We met our participants on four different occasions during this examination. In the first session, we tested creative thinking by applying the Unusual Uses Test and 
Table 2. Descriptive statistics and tests of normality of the examined variables

\begin{tabular}{|c|c|c|c|c|c|c|c|c|}
\hline Scales $^{\mathrm{a}}$ & Min & $\operatorname{Max}$ & $M d n$ & $M$ & $S D$ & Skewness $^{\mathrm{b}}$ & Kurtosis $^{\mathrm{b}}$ & $\begin{array}{r}\text { Kolmogorov- } \\
\text { Smirnov Z } \\
\end{array}$ \\
\hline Academic average & 2.10 & 5.00 & 3.90 & 3.86 & 0.57 & -0.24 & -0.52 & $1.54^{*}$ \\
\hline JB2: Re-editing & 0.00 & 100.00 & 25.00 & 29.74 & 24.34 & 0.66 & -0.22 & $4.62^{*}$ \\
\hline JB2: Direct info-management & 0.00 & 100.00 & 62.50 & 56.58 & 20.82 & -0.34 & -0.44 & $4.29^{*}$ \\
\hline JB2: Indirect info-management & 0.00 & 100.00 & 50.00 & 45.57 & 21.74 & 0.09 & -0.32 & $3.27^{*}$ \\
\hline JB2: Holistic learning & 0.00 & 100.00 & 25.00 & 30.77 & 21.03 & 0.21 & -0.73 & $3.56^{*}$ \\
\hline JB2: Total Score & 3.13 & 93.75 & 40.62 & 40.66 & 16.16 & 0.22 & -0.29 & $1.75^{*}$ \\
\hline APM: Total Score & 11.00 & 47.00 & 31.00 & 30.36 & 5.39 & -0.59 & 0.45 & $2.59^{*}$ \\
\hline LAQ: Internal motivation & 1.80 & 4.60 & 3.40 & 3.37 & 0.49 & -0.27 & 0.08 & $1.90^{*}$ \\
\hline UUT: Fluency & 1.00 & 48.00 & 9.00 & 10.08 & 5.29 & 1.14 & 3.58 & $2.64^{*}$ \\
\hline UUT: Originality & 0.37 & 29.00 & 5.27 & 5.80 & 3.49 & 1.54 & 4.82 & $2.36^{*}$ \\
\hline UUT: Flexibility & 0.00 & 19.00 & 8.00 & 7.81 & 3.53 & 0.40 & -0.08 & $2.23^{*}$ \\
\hline UUT: Average originality & 0.17 & 3.00 & 0.53 & 0.59 & 0.26 & 3.60 & 19.43 & $6.44^{*}$ \\
\hline UUT: Relative flexibility & 0.00 & 12.00 & 0.83 & 0.83 & 0.43 & 20.95 & 535.67 & $9.51^{*}$ \\
\hline
\end{tabular}

a JB2: Jupiter Flea test, APM: Advanced Progressive Matrices test, LAQ: Learning Attitude Questionnaire, UUT: Unusual Uses test

${ }^{\mathrm{b}} S E_{\text {Skewness }}=.09 ; S E_{\text {Kurtosis }}=.17$

we also applied the Learning Attitude Questionnaire. On the second occasion participants filled in the APM test. The JB2 was applied during the third session. At the final session, we discussed the results with the participants. Every session lasted around 45 minutes, and was held at their school.

\section{Results}

According to the Kolmogorov-Smirnov test (Table 2), the distributions of researched variables were not normal ( $p<.05$ in all cases). However, the values of skewness and kurtosis are near zero in several cases (the absolute value of the difference from zero is less than 1 for skewness and this difference is less than 3 for kurtosis), so we could use parametric tests for these variables. However, the skewness and kurtosis of about half of our variables are higher, therefore we consistently used non-parametric statistical tests.

Table 2 shows that the mean values of JB2 variables and information-processing achievements are at fairly low levels. The results of about $75 \%$ of the participants are less than $50 \%$ in re-editing and holistic learning. Approximately $50 \%$ of participants scored less than $50 \%$ in the case of indirect info-management. It seems that direct info-management was the easiest task of the JB2 because a significant proportion of participants achieved a result above $50 \%$. Overall, the JB2 total score was less than $50 \%$ in most cases.

Table 3. Mean ranks and the results of the Kruskal Wallis test for testing the differences on the used variables between the school grades

\begin{tabular}{lccccr}
\hline \multirow{2}{*}{ Variables } & \multicolumn{4}{c}{ Mean rank of grade } & \multicolumn{1}{c}{$12^{\text {th }}$} \\
\cline { 2 - 5 } & $9^{\text {th }}$ & $10^{\text {th }}$ & $\chi^{2}(d f=3)$ \\
\hline Academic average & 401.79 & 376.49 & 441.19 & 433.17 & $10.33^{*}$ \\
Re-editing & 372.30 & 381.68 & 452.28 & 466.29 & $23.10^{*}$ \\
Direct info-management & 355.37 & 392.79 & 441.18 & 502.53 & $34.21^{*}$ \\
Indirect info-management & 382.58 & 393.69 & 417.88 & 485.84 & $15.28^{*}$ \\
Holistic learning & 352.07 & 432.98 & 422.64 & 444.74 & $20.19^{*}$ \\
Total Score & 348.25 & 396.87 & 444.39 & 501.80 & $36.80^{*}$ \\
APM & 362.18 & 428.18 & 433.58 & 408.64 & $13.56^{*}$ \\
Internal motivation & 417.25 & 407.54 & 402.71 & 398.51 & 0.64 \\
Fluency & 400.03 & 374.35 & 442.27 & 440.74 & $12.17^{*}$ \\
Originality & 411.89 & 413.88 & 402.19 & 395.81 & 0.62 \\
Flexibility & 406.26 & 363.30 & 442.75 & 453.96 & $18.04^{*}$ \\
Average originality & 426.92 & 458.73 & 360.06 & 328.94 & $33.79^{*}$ \\
Relative flexibility & 419.09 & 392.00 & 410.69 & 417.69 & 1.97 \\
\hline
\end{tabular}

${ }^{*} p<.05$ 
Table 4. Spearman's rho correlations between all examined variables

\begin{tabular}{|c|c|c|c|c|c|c|c|c|c|c|c|c|}
\hline Variables $^{\mathrm{a}}$ & 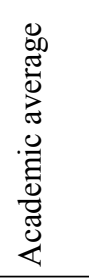 & 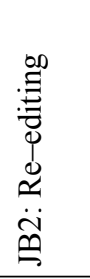 & 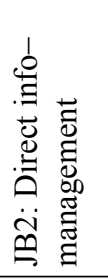 & 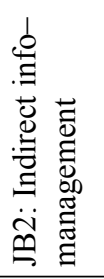 & 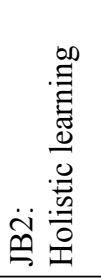 & 苛 & 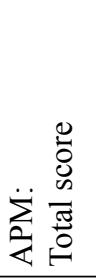 & 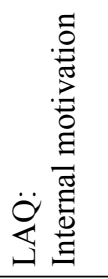 & 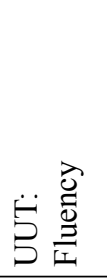 & 苍葶 & 它 & 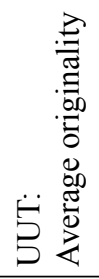 \\
\hline $\begin{array}{l}\text { JB2: } \\
\text { Re-editing }\end{array}$ & .05 & & & & & & & & & & & \\
\hline $\begin{array}{l}\text { JB2: Direct } \\
\text { info-management }\end{array}$ & $.13^{*}$ & $.28^{*}$ & & & & & & & & & & \\
\hline $\begin{array}{l}\text { JB2: Indirect } \\
\text { info-management }\end{array}$ & $.16^{*}$ & $.35^{*}$ & $.49^{*}$ & & & & & & & & & \\
\hline $\begin{array}{l}\text { JB2: } \\
\text { Holistic learning }\end{array}$ & $.11^{*}$ & $.46^{*}$ & $.34^{*}$ & $.34^{*}$ & & & & & & & & \\
\hline $\begin{array}{l}\text { JB2: } \\
\text { Total score }\end{array}$ & $.13^{*}$ & $.72^{*}$ & $.71^{*}$ & $.73^{*}$ & $.72^{*}$ & & & & & & & \\
\hline $\begin{array}{l}\text { APM: } \\
\text { Total score }\end{array}$ & $.49^{*}$ & $.18^{*}$ & $.17^{*}$ & $.23^{*}$ & $.23^{*}$ & $.27^{*}$ & & & & & & \\
\hline $\begin{array}{l}\text { LAQ: } \\
\text { Internal motivation }\end{array}$ & .01 & -.02 & -.01 & -.01 & -.01 & -.03 & .00 & & & & & \\
\hline $\begin{array}{l}\text { UUT: } \\
\text { Fluency }\end{array}$ & .07 & .03 & .04 & $.10^{*}$ & .06 & $.08^{*}$ & -.03 & .00 & & & & \\
\hline $\begin{array}{l}\text { UUT: } \\
\text { Originality }\end{array}$ & .04 & .04 & .00 & $.08^{*}$ & .03 & .05 & -.01 & .01 & $.84^{*}$ & & & \\
\hline $\begin{array}{l}\text { UUT: } \\
\text { Flexibility }\end{array}$ & $.07^{*}$ & $.08^{*}$ & $.08^{*}$ & $.08^{*}$ & $.09^{*}$ & $.11^{*}$ & -.02 & -.01 & $.90^{*}$ & $.74^{*}$ & & \\
\hline $\begin{array}{l}\text { UUT: } \\
\text { Average originality }\end{array}$ & -.02 & .05 & -.02 & -.03 & -.01 & .00 & .04 & $.08^{*}$ & $-.09^{*}$ & $.37^{*}$ & $-.08^{*}$ & \\
\hline $\begin{array}{l}\text { UUT: } \\
\text { Relative flexibility }\end{array}$ & -.04 & .07 & $.07^{*}$ & -.07 & .03 & .04 & $.07^{*}$ & -.02 & $-.48^{*}$ & $-.49^{*}$ & $-.11^{*}$ & .02 \\
\hline
\end{tabular}

a JB2: Jupiter Flea test, APM: Advanced Progressive Matrices test, LAQ: Learning Attitude Questionnaire, UUT: Unusual Uses test

According to the results of the Mann-Whitney $U$ test, there are significant differences between males and females in terms of direct and indirect information management $(U=49827.50$ and 56304.00 ; in both cases $p$ $<.05$ ). Females' results (mean rank $=417.15$ and 427.72) were better in these areas than males' results (mean rank $=348.17$ and 380.23). It should be noted that the females' academic averages were also better $(U=53786.50 ; p<$ .05 ; mean rank of male $=367.77$; mean rank of female $=$ 421.26) but we did not find significant differences between genders in terms of intelligence (this finding confirms the results of Brody, 1992; Halpern \& LaMay, 2000; Jensen, 1998). Besides, the Kruskall Wallis test showed significant differences among grades in the following variables (Table 3):

- participants from higher grades generally had better results on the APM and all the JB2 variables;
- participants from $10^{\text {th }}$ grades had lower results in academic average, fluency and flexibility;

- in terms of average originality, the $9^{\text {th }}$ and $10^{\text {th }}$ grades students had better results than their $11^{\text {th }}$ and $12^{\text {th }}$ grade peers.

Table 4 shows the Spearman's correlations among the variables; there are only two high correlations, i.e. between fluency and originality $(r=.84)$ and fluency and flexibility $(r=.90)$. A moderate correlation is found between originality and flexibility $(r=.74)$ and between the total score and the subscales of the JB2 test $(r=.71$ - .73). We can see slightly weaker relations between intelligence and academic average $(r=.49)$, originality and relative flexibility $(r=-.49)$, fluency and relative flexibility $(r=-.48)$, originality and average originality $(r=.37)$. In the cases of other significant correlations, $r$ values are less than .30 . 


\section{Discussion}

According to our results, a significant proportion of students do not use spontaneously productive (creative) information-processing methods for learning. If they meet a confused (or maybe over-long) text, they do not re-edit the text, they do not look for the direct (explicit essential facts) and indirect (implicit but deducible) information, and they do not seek the cross-relations among the subjects, books, chapters or paragraphs. This is a problem in two senses. Firstly, their school learning would be more effective in terms of understanding, timing etc., if they used productive learning methods. Secondly, their poorer information processing strategy could cause disadvantages during their adult life, in the labour market, and in business life and family life.

The test results indicate that predicting the academic average is practically impossible, either from the results of creativity tests or from students' knowledge of information-processing approaches to creative learning or internal motivation. Behind these facts, it is assumed that the teachers are inconsistent when they evaluate the learners' school achievements, and they do not differentiate among students based on motivational dispositions such as learning attitude. It is probable that they often require reproductive learning for good marks, and they sometimes do not require productive (creative) learners. This hypothesis can be tested by observation and content analysis of real exam situations.

The correlation between intelligence and academic average was $r=.49$, and this is similar to previous findings (see Neisser et al., 1996). However, the correlations show that higher intelligence is not necessarily associated with more productive information processing during learning, something which also corresponds with other researchers' results (Balogh, 2004). This also means that the development of creative (productive) learning and thinking may be a necessary component of talent development programs in the area of intellectual talent, too (Mezö, 2011). Given that intelligence does not correlate with internal learning motivation, motivationoriented programs may be also central elements of talent development programs for children of high intellectual ability.

In this study we have observed that although the creativity variables of the Unusual Uses Test correlate strongly with each other (confirming the results of Cropley, 2003), these barely correlate with variables of creative information-processing (measured by the JB2 test). This is explained by the fact that the Unusual Uses test and the JB2 test focused on other aspects of the creative process and products. The Unusual Uses test is directed at the number and variety of novel ideas (as a kind of creative product); these kinds of ideas can give information about a type of creative thinking (such as information processing). In contrast, the number, variety and novelty of ideas are less important for the JB2 test, although when dealing with a confused text it is important to create a new logical structure which contains essential information and conclusions, and holistic relationships. It seems that this approach is more lifelike and occurs more frequently during school learning than the "fluency", "flexibility" and "originality" orientated approaches of the Unusual Uses test. The result also shows that the role of classic creative abilities (e.g. fluency, originality and flexibility) is limited during school learning and teaching - this has been well known since the 1950s (e.g., Guilford, 1962). However, it should be noted that these creative abilities might play an important role in the case of outof-school learning, autodidact learning, and in the school itself (when students do not learn, but create knowledge during an oral/written exam).

Finally, we should note that we did not find gender differences in the case of intelligence or creativity, but we found that females have better academic averages and information management.

\section{Limitations}

A potential drawback concerns the rather specific sample, which was not randomly selected from the full range of possible secondary school students. Another problem is that the gender ratio is not balanced (male students are under-represented in this sample) and does not mirror the boys to girls ratio in the schools. At the same time, we are convinced that our sample was sufficiently heterogeneous and our other data (from observations in schools in exam situations and interviews with teachers - these are currently being processed) confirm the results of this study.

Another limitation of this study is that just one test was used to measure the information-processing characteristics of learning (creative learning), and that this test was verbal, similar to the creativity test, which restricts the generalizability of the results.

\section{Future Research and Implications for Practice}

The future development of the JB2 will aim to improve its psychometric characteristics, and also to make it shorter. It would be important to examine information processing characteristics during (creative) learning across different age groups and cultures.

The practical implications refer to the need for more learning development programs, which focus on productive learning methods (nowadays we know of only one learning development program, which fits this purpose: the IPOO-creative learning program). On the other hand, it is important that this program becomes a fundamental component and part of teacher training. In order to achieve this aim, we need to develop better learning-diagnostic instruments, methods, protocols and teacher training programs than our presently available instruments and methods. 


\section{Conclusions}

The observable creative information-processing characteristics of secondary school students' learning are of disappointingly poor quality (independently of their cognitive abilities, learning motivation etc.). From a retrospective viewpoint, we should explore these factors (e.g. the role of education, the curriculum, teaching materials, teachers' evaluation practice etc.) which induce these results. On the other hand, from a prospective viewpoint, we should develop and teach those methods of teaching and learning which can increase the quality of the creative information-processing aspect of learning.

Our results have shown that cognitive abilities, the internal motivation for learning, the academic average and the information processing style of learning are, taken individually, fairly unreliable in terms of their use in making predictions about other factors. One practical consequence of these results is that we have to handle these learning variables separately when we want to test and/or develop them.

\section{References}

Balogh, L. (2004). Iskolai tehetséggondozás [Talent development in school]. Debrecen, Hungary: Kossuth Egyetemi Kiadó.

Baer, J. (2012). Gender differences in creativity. In M. A. Runco (Ed.), Creativity research handbook (Vol. 3, pp. 215-250). New York, NY, USA: Hampton Press.

Barkóczi, I., \& Zétényi, T. (1981). A kreativitás vizsgálata [Examination of the creativity]. Budapest, Hungary: Országos Pedagógiai Intézet.

Bloom, B. S. (1968). Learning for mastery. Evaluation Comment, 1(2), (unpaginated).

Brody, N. (1992). Intelligence (2nd ed.). San Diego, CA, USA: Academic Press.

Bruner, J. S. (1961). The act of discovery. Harvard Educational Review, 31(1), 21-32.

Carroll, J. B. (1963). A model of school learning. Teachers College Record, 64, 723-733.

Craft, A., Cremin, T. Burnard, P., \& Chappell, K. (2007). Teacher stance in creative learning: A study of progression. Journal of Thinking Skills and Creativity, 2(2), 136-146.

Cropley, A. J. (1997). Fostering creativity in the classroom: General principles. In M. A. Runco (Ed.), Handbook of creativity (pp. 81-112). Cresskill, NJ, USA: Hampton Press.

Cropley, A. J. (2003). Creativity in the education and learning: A guide for teachers and educators. London, UK: Kogan Page.

Davis, G. (1992). Creativity is forever. Dubuque, IA, USA: Kendall.

Feist, J. G., \& Runco, M. A. (1993). Trends in the creativity literature: An analysis of research in the Journal of Creative Behavior (1967-1989). Creativity Research Journal, 6(3), 271-283.
Furnham, A., Clark, K., \& Bailey, K. (1999). Sex differences in estimates of multiple intelligences. European Journal of Personality, 13, 247-259.

Galperin, P. Ya. (1989). Organization of mental activity and effectiveness of learning. Soviet Psychology, 27(3), 65-82.

Gordon, K. A., \& Austin, J. T. (2002). The relationship of gender and academic performance to motivation: Within-ethnic-group variations. The Urban Review, 34(4), $293-316$.

Guilford, J. P. (1950). Creativity. American Psychologist, $5,444-454$.

Guilford, J. P. (1962). Creativity: Its measurement and development. In J. J. Parnes \& H. F. Harding (Eds.), A source book for creative thinking (pp. 151-168). New York, NY, USA: Scribners.

Halpern, D. F., \& LaMay, M. L. (2000). The smarter sex: A critical review of sex differences in intelligence. Educational Psychology Review, 12(2), 229-246.

Helmholtz, H. v. L. (1896). Vorträge und Reden [Presentations and speeches] (5thed.). Braunschweig, Germany: Friederich Vieweg und Sohn.

Hyde, J. S. (2005). The gender similarities hypothesis. American Psychologist, 60, 581-592.

Jeffrey, B. (Ed) (2006). Creative learning practices: European experiences. London, UK: Tufnell Press.

Jensen, A. R. (1998). The G factor: The science of mental ability. Westport, CT, USA: Praeger.

Józsa, K. (2000). Az iskola és a család hatása a tanulási motivációra [Effect of the school and family on learning motivation]. Iskolakultúra [School culture], $8,69-82$.

Kontra, J. (2006). Középiskolások tanulás iránti attitüdje [Learning attitude of secondary school students]. Képzés és Gyakorlat [Education and Practice], 4(1), 28-32.

Kris, E. (1953). Psychoanalysis and the study of creative imagination. Bulletin of the New York Academy of Medicine, 29, 334-351.

Lynn, R., Irwing, P., \& Cammock, T. (2002). Sex differences in general knowledge. Intelligence, 30(1), 27-39.

Lucas, B. (2001). Creative teaching, teaching creativity and creative learning. In A. Craft, B. Jeffrey, \& M. Leibling (Eds.), Creativity in education (pp. 35-47). London, UK: Continuum.

McLaurin, W., Jenkins, J., Farrar, W., \& Rumore, M. (1973). Correlations of IQ on verbal and non-verbal tests of intelligence. Psychological Reports, 22, 821-822.

Mező, F. (2011). Learning development by IPOOminimum program. In I. Pšenáková (Ed.), Science For Education - Education For Science (pp. 241-246). Nitre, Slovakia: Faculty of Central European Studies of Constantine the Philosopher University in Nitra.

Mező,F.,\&Kurucz, Gy.(2014).AzAPMintelligenciateszttel kapcsolatos vizsgálati tapasztalatok a Debreceni Egyetem tehetséggondozó Programjában 20022008 között. [Experiences of the APM intelligence 
test in the talent development program of University of Debrecen between years 2002-2008]. Budapest, Hungary: Magyar Tehetségsegítő Szervezetek Szövetsége.

Neisser, U., Boodoo, G., Bouchard, T. J., Boykin, A. W., Brody, N., Ceci, S. J., Urbina, S. (1996). Intelligence: Knowns and unknowns. American Psychologist, 51(2), 77-101.

Petersen, J. L., \& Hyde, J. S. (2010). A meta-analytic review of research on gender differences in sexuality, 1993-2007. Psychological Bulletin, 136, 1, 21-38.

Raven, J., Raven, J. C., \& Court, J. H. (1998). Manual for Raven's Progressive Matrices and Vocabulary Scales. Section 4: The Advanced Progressive Matrices. San Antonio, TX, USA: Harcourt Assessment.

Rózsa, S. (2006). Raven Progszív Mátrixok: Kézikönyv. [Raven Progresive Matrixes: Handbook] Budapest, Hungary: OSHungary.

Runco, M. A. (2007). Creativity: Theories and themes: Research, development, and practice. Amsterdam, Netherlands: Elsevier Academic Press.

Ryan, R. M., \& Deci, E. L. (2000). Intrinsic and extrinsic motivations: Classic definitions and new directions. Contemporary Educational Psychology, 25, 54-67.

Stein, M. I. (1974). Stimulating creativity. New York, NY: Academic Press.

Strenberg R. J., \& Grigorenko, E. L. (2007). Teaching for successful intelligence: To increase student learning and achievement. Thousand Oaks, CA, USA: Corwin Press.

Sternberg, R. J., \& Lubart, T. I. (1999). The concept of creativity: Prospects and paradigms. In R. J. Sternberg (Ed.), Handbook of creativity (pp. 3-15). Cambridge, UK: Cambridge University Press.

Sullo, B. (2007). Activating the desire to learn. Alexandria, VA, USA: Association for Supervision and Curriculum Development.

Torrance, E. P. (1966). The Torrance Tests of Creative Thinking-Norms-Technical Manual Research EditionVerbal Tests, Forms A and B-Figural Tests, Forms A and $B$. Princeton, NJ, USA: Personnel Press.

Wallas, G. (1926). The art of thought. New York, NY, USA: Harcourt Brace.

Whiting, C. S. (1958). Creative thinking. New York, NY, USA: Reinhold. 